\title{
Comparative Evaluation of Financing Methods Based of ROA, ROE, Debt ratio, EPS and DPS in Automotive and Petrochemical Industry' Companies Listed in Tehran Stock Market
}

\author{
Amin Farmahini Farahani' ${ }^{1}$, Roya Darabi ${ }^{2}$ \\ Received:20.08.2015 \\ Revised:25.09.2015 \\ Accepted: 30.11.2015
}

\begin{abstract}
There is a doubt about benefit about eternal financing or financing through debt for maximizing the benefits. The purpose of the present study is to study profitability ratios in the selection of the method of providing financial resources through increasing capital and debt. The society under research is shareholding companies in Tehran from the year 1387 to the year 1392. According to the criteria for entering the society, in general, 67 companies were selected. Out of these 67 companies, 35 companies were selected out of the investment method and 32 were selected out of the debt method. The data are analyzed through descriptive statistics, non-parametric tests and SPSS 21 in the meaningful level of $\% 05$. This study will show that there is not a significant statistical difference between providing financial resources through the debt method or the investment method in the four variables of ROE, DPS, EPS, and Debt Ratio. However, in the variable of ROA, there is a significant difference between the two methods: $(p=0.015)$. That is to say, the profitability ratio is higher in the companies that provide their financial resources through shares compared to the companies that provide their financial resources through debt.
\end{abstract}

Keywords: Capital Structure, Portability ratio, Tehran stock exchange.

\section{Introduction}

This study focuses on the association between capital structure \& profitability of automotive and petrochemical industry' companies listed in Tehran stock market. Capital structure is one of the most confusing issues in corporate finance literature (Brounen \& Eichholtz, 2001). Debt and equity are two external sources of financing for companies. The combination of debts and equities is called capital structure. Companies try to balance combination of these two external sources of financing to maximize the companies' shareholders value. According to Modigliani and Miller (1981) the best mixture of debts and equities and therefore the capital structure is irrelevant because the value of company is determined by the value of real assets, not by the proportion of debts and equities. Furthermore some studies showed that there is no optimal capital structure for a company (Vasiliou et al, 2009). According to this, studies companies prefer internal financing (income, amortization) and only in a situation when internal cash flow is not sufficient for activity financing, they reach

\footnotetext{
Author's Address

${ }^{1}$ Department of Governmental Management, Faculty of

Management, Central Tehran Branch, Islamic Azad University (I.A.U), Tehran, Iran

${ }^{2}$ Organizations and Methods Group, Department of Governmental Management, Faculty of Management, Central Tehran Branch, Islamic Azad University (I.A.U), Tehran, Iran

Email:amir67kabir@yahoo.com,
}

for foreign capital (loans, credits). But normally combination of debt $\&$ equity that make the total capital of firms. So proportion of debt to equity is a strategic choice of corporate managers and capital structure decision is the vital one since the profitability of an enterprise is directly affected by such decision. For this reason, enough attention need to be given while determining capital structure decision. Unplanned capital structure can lead to companies fail to economize the use of their funds (Velnampy and Niresh, 2012). Abor (2005) emphasized that capital structure decision is crucial for any business organization that aims at maximizing returns to various organizational constituencies. The importance of capital structure decision is come from its impact on a firm's ability to deal with its competitive environment. As a result, the determination of appropriate choice and mix of debt and equity that would maximize the market value of companies is very important. Gowthorpe (2003) showed that success or failure of financial performance of a company is assessed by profitability ratios. To understand how automotive and petrochemical industry' companies listed in Tehran stock market finance their operations to maximize profits, it is necessary to examine the effect of leverage on their performance. In this study, the effort will be made to clarify the relationship between capital structure and profitability ratios including: Return on equity (ROE), Return on Asset (ROA), 
Debt ratio, Earnings Per Share (EPS), Dividend Per Share (DPS) in automotive and petrochemical industry' companies listed in Tehran stock market

\section{Statement of the Problem}

Determination of combination of optimal capital structure is one of the objectives and main decisions of corporate executives in reaching to maximization of wealth of stockholders and take economists, company managers and investors of companies into the consideration. Cash balance also with considering its different effects (not only can optimize the performance and increase the value of company by investment in profitable projects but also by investment in risky projects can decrease the value of company) is constantly important for potential investors and managers of companies.

Therefore, this study mostly analyses how far the capital structure affects the profitability ratios of corporate firms in automotive and petrochemical industry listed in Tehran stock market. Profitability ratios appear to be the important indicator in determining the profitability of corporate firms. We selected all listed automotive and petrochemical industry' companies in Tehran stock market companies from 2001 till 2014 (by considering the two conditions: existence of the needed variables and presence in TSE in this period). Therefore, financial information of 62 automotive and petrochemical industry' companies which were active in TSE qualified in this stage were derived out of the balance sheets and income statements.

\section{Theoretical Foundation of Research}

Decisions related to financing, as one of the main decision of financial managers, should be performed in direction of maximization of wealth of stockholders. Publication of paper of Modigliani and Miller (1958) is the beginning of attention to capital structure as one of the main factor of determination of company value. The aforementioned researches have stated that in case of not existence of income tax, capital structure and market value are independent. Modigliani and Miller in 1963 by revision in their first theory stated that using liability in capital structure will decrease the income tax payable of company. Consequently, more use of liability will lead to increase of firm value.

\section{Review on Performed Researches}

The Concept is generally described as the combination of debt $\&$ equity that make the total capital of firms. The proportion of debt to equity is a strategic choice of corporate managers. Capital structure decision is the vital one since the profitability of an enterprise is directly affected by such decision. Hence, proper care and attention need to be given while determining capital structure decision. In the statement of affairs of an enterprise, the overall position of the enterprise regarding all kinds of assets, liabilities are shown. Capital is a vital part of that statement. The term "capital structure" of an enterprise is actually a combination of equity shares, preference shares and long-term debts. A cautious attention has to be paid as far as the optimum capital structure is concerned. Sarkar and Zapatero (2003) Found a positive relationship between leverage and profitability. Myers and Majluf (1984)

Found that firms that are profitable and generate high earnings are expected to use less debt capital comparing with equity than those that do not generate high earnings. Chiang et al., (2002) results show that profitability and capital structure are interrelated; the study sample includes 35 companies listed in Hong Kong. Raheman et al., (2007) find a significant capital structure effect on the profitability for nonfinancial firms listed on Islamabad Stock Exchange. The data for a period of 8 years ranging from 1999-2000 to 2006-2007 have been collected and considered for analysis by Azhagaiah and Gavoury (2009).

Regression Analysis (to analyze the unique impact of capital structure on Profitability), in addition to descriptive statistics such as Mean, Standard Deviation, and Ratios has been used. The study proved that there has been a strong one-to-one relationship between capital structure variables and Profitability variables like Return on Assets (ROA) and the capital structure has significant influence on Profitability, and increase in use of debt fund in capital structure tends to minimize the net profit of the it firms listed in Bombay Stock Exchange in India. Most studies found a negative relationship between profitability and leverage. Within this framework, Titman \& Wessels (1988) contend that firms. with high profit levels, all things being equal, would maintain relatively lower debt levels since they can realize such funds from internal sources. Furthermore, Kester (1986) found a significantly negative relation between profitability and debt/asset ratios. Rajan \& Zingalas (1995) also confirmed a significantly 
negative correlation between profitability and leverage in their work. Despite the above empirical works, some authors are of a different opinion. Chiang Yat Hung, Chan Ping Chuen Albert \& Hui Chi Man Eddie (2002) shows the inter-relationship between profitability, cost of capital and capital structure The Relationship between Capital Structure \& Profitability Global Journal of Management and Business Research among property developers and contractors in Hong Kong. The data for this research paper was collected from Datastream, an electronic financial database.

The analysis of this paper shows that gearing is generally higher among contractors than developers and capital Lalith, P.S (1999) investigated the capital structure of Srilankan companies and found that the use of long-term debt is relatively low in Srilankan companies. The mean leverage in Sri Lanka is estimated as $13.5 \%$, long term debt to equity ratio is $24 \%$ while the total debt to equity ratio is $104.1 \%$. This evidence suggested that the use of debt financing in Sri Lanka is significantly low in comparison to G7 markets. Gearing is positively related with asset but negatively with profit margins. Barclay and Smith (2005) argued that companies with few investment opportunities and substantial free cash flow will have low (or even negative) debt ratios because the cash will be used to pay down the debt.

It may also suggest that high-growth firms with lower operating cash flow will have high debt ratios because of their reluctance to raise new equity. It should be noted that where there is no existence of information asymmetry, the firm will then turn to debt if additional funds are needed, and finally issue equity to cover any remaining capital requirements. It is clear at this point that, firms would prefer internal sources to costly external finance

\section{Research Hypothesis}

Considering the theoretical foundation and performed researches, this research is presented as below:
H1: There is a significant difference between return on investment (ROI) in companies financed through debt and companies financed through shares

H2: There is a significant difference between Return on Asset (ROA) in companies financed through debt and companies financed through shares

H3: There is a significant difference between Debt ratio in companies financed through debt and companies financed through shares

H4: There is a significant difference between Earnings per Share (EPS)in companies financed through debt and companies financed through shares

H5: There is a significant difference between Dividend per Share (DPS) in companies financed through debt and companies financed through shares

\section{Research Method}

According to Jankowicz, (1994) generalization about the population from data collected using any sample is based on probability. In order to be able to generalize about the research finding to the population, it is necessary to select samples of sufficient size. A large sample size will in general improve the quality of the research. A large sample size is always better than a small one. Saunders, Lewis and Thornhill (1996) also point out that the larger the sample size, the lower the likely error in generalising the population. Correlation method is used in this research and in terms of objective is an applied one. Also, the project is semi-experimental due to using historical data.

Statistical population of this research is all the companies in the Tehran stock exchange during the period of 2007 to 2103. Sample of research comprise of companies in the Tehran stock exchange until the end of 2013, which their fiscal periods ending on March 20, 2006, it hasn't been changed in this period and required data for this research is available. According to the considered constraints, 149 companies (in all years) are selected as final sample of research. Research model is shown in graph 1. 


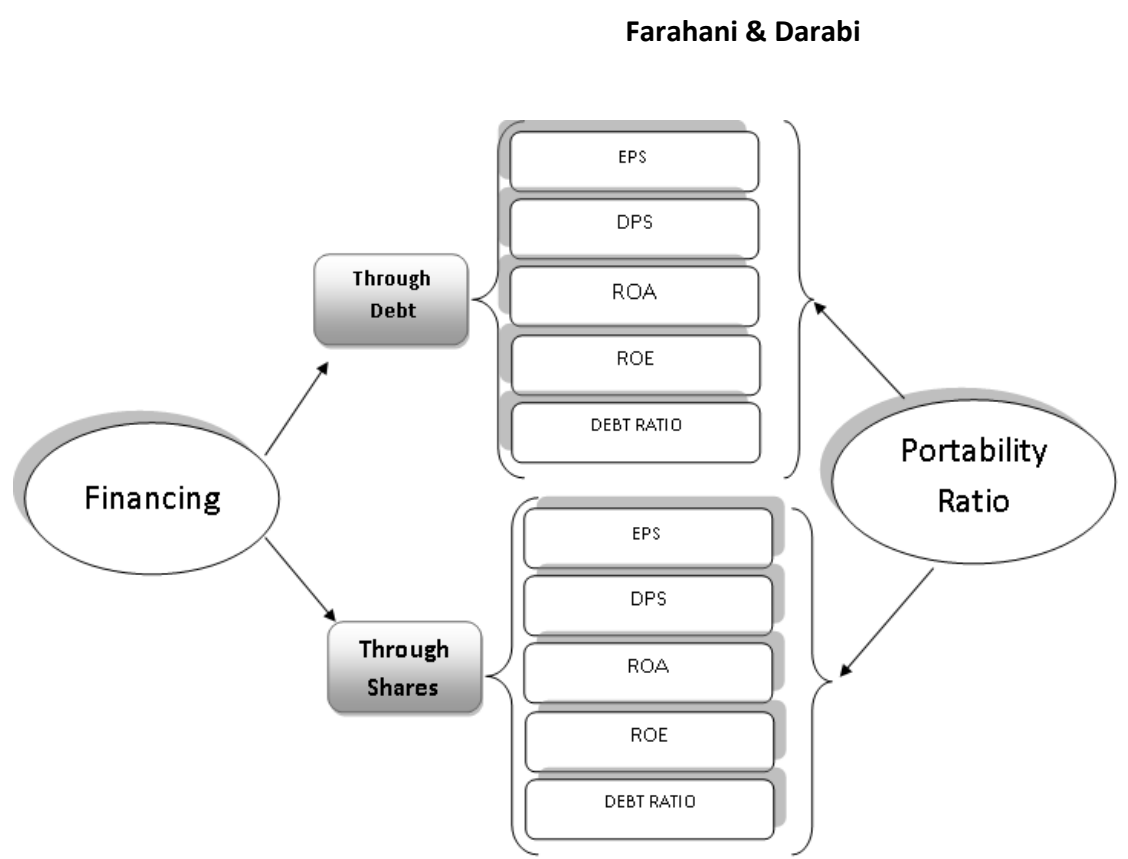

Graph 1: Research model of the study

Variables of the study include:

Return on assets $(R O A)=\frac{\text { Net Incom }}{\text { Total Assets }}$

Return On Equity $(R O E)=\frac{\text { Annual Net Income }}{\text { Average Stockholders' Equity }}$

Earnings Per Share $(E P S)=\frac{\text { Net Income }}{\text { Average Outstanding Common Shares }}$

debt Ratio $=\frac{\text { Total liabilities }}{\text { Total assets }}$

Dividends Per Share (DPS)

$=\frac{\text { Annual Net IncoSum of dividends over a periodme }- \text { Special, one time dividends }}{\text { Shares outstanding for the period }}$

In this study Portability ratio are dependent We used descriptive statistics to analyze and variables and financing is independent variable. describe the data. The one-sample KolmogorovControl variable include firm size for this Smirnov test used to test those variables is research. normally distributed. Table 2 shows result of

6.Empirical Results Kolmogorov-Smirnov test.

Table 1: descriptive statistics of the studied variables

\begin{tabular}{llllllll}
\hline & Range & Minimum & Maximum & Mean & $\begin{array}{l}\text { Std. } \\
\text { Deviation }\end{array}$ & Variance & Range \\
\hline ROA & -25.54 & 74.03 & 14.9873 & 14.9873 & 20.57474 & 423.320 & 99.57 \\
ROE & -62.49 & 948.65 & 47.1481 & 47.1481 & 121.91991 & 14864.465 & 1011.14 \\
Debt & .03 & 1.73 & .6184 & .6184 & .30239 & .091 & 1.70 \\
Ratio & & & & & & & \\
DPS & - & 9145.00 & 1542.9000 & 1542.9000 & 2397.54681 & 5748230.702 & 10294.00 \\
& 1149.00 & & & & & & \\
EPS & .00 & 8000.00 & 1303.8500 & 1303.8500 & 2065.68719 & 4267063.553 & 8000.00 \\
\hline
\end{tabular}


Table 1: Kolmogorov-Smirnov test for normality distribution

\begin{tabular}{|c|c|c|c|c|c|c|}
\hline & & ROA & ROE & NesbatBE & EPS & DPS \\
\hline $\mathrm{N}$ & & 62 & 62 & 62 & 62 & 62 \\
\hline Normal Parameters & Mean & 14.9873 & 47.1481 & .6184 & 1303.8500 & 1542.9000 \\
\hline \multirow{3}{*}{$\begin{array}{l}\text { Most Extreme } \\
\text { Differences }\end{array}$} & $\begin{array}{l}\text { Std. } \\
\text { Deviation }\end{array}$ & 20.57474 & 121.91991 & .30239 & 2065.68719 & 2397.54681 \\
\hline & Absolute & .159 & .329 & .065 & .274 & .210 \\
\hline & $\begin{array}{l}\text { Positive } \\
\text { Negative }\end{array}$ & $\begin{array}{l}.159 \\
-.120\end{array}$ & $\begin{array}{l}.329 \\
-.250\end{array}$ & $\begin{array}{l}.065 \\
-.041\end{array}$ & $\begin{array}{l}.274 \\
-.264\end{array}$ & $\begin{array}{l}.210 \\
-.150\end{array}$ \\
\hline $\begin{array}{l}\text { Kolmogorov- } \\
\text { Smirnov Z }\end{array}$ & & 1.254 & 2.588 & .510 & 2.125 & 1.627 \\
\hline $\begin{array}{l}\text { Asymp. Sig. (2- } \\
\text { tailed) }\end{array}$ & & .086 & .060 & .957 & .231 & .070 \\
\hline
\end{tabular}

Kolmogorov-Smirnov test have shown that all variables have normal distribution. Independent samples tes (T-Test) along with Levine's test for equality of variances was used for evaluation of hypothesis. Results are shown in table 3 and 4.

Table 3: Levine's test for equality of variances for all variables

\begin{tabular}{cccc}
\hline Variables & Assumetion & Levene's Test for Equality of Variances \\
& & $\mathrm{F}$ & Sig. ( P.Value) \\
\hline ROA & Equal variance assumed & .531 & .397 \\
ROE & Equal variance assumed & .261 & 1.286 \\
Debt Ratio & Equal variance assumed & .381 & .780 \\
EPS & Equal variance assumed & .386 & .764 \\
DPS & Equal variance assumed & .936 & .007 \\
\hline
\end{tabular}

For Independent samples test statistical hypothesis is shown below:

$\mathrm{H} 0: \mathrm{u} 1=\mathrm{u} 2$

$\mathrm{H} 1: \mathrm{u} 1 \neq \mathrm{u} 2$

H0: ROA, ROE, Debt Ratio, EPS and DPS in companies financed through shares have significant difference with companies financed through Debt.

H1: ROA, ROE, Debt Ratio, EPS and DPS in companies financed through shares have no significant difference with companies financed through Debt. Table 4 shows Independent samples test (T-Test) for all variables.

Table 4: Independent samples test (T-Test) for all variables.

\begin{tabular}{|c|c|c|c|c|c|c|}
\hline & $\mathbf{t}$ & $\mathbf{d f}$ & $\begin{array}{c}\text { Sig. (2- } \\
\text { tailed) }\end{array}$ & Mean Difference & $\begin{array}{c}\text { Std. Error } \\
\text { Difference }\end{array}$ \\
\hline ROA & $\begin{array}{c}\text { Equal variances } \\
\text { assumed }\end{array}$ & -.182 & 61 & .034 & -.9470728759545 & 5.1997919639275 \\
\hline ROE & $\begin{array}{c}\text { Equal variances } \\
\text { assumed }\end{array}$ & .625 & 61 & .534 & 19.1338980697496 & 30.6216316176877 \\
\hline $\begin{array}{c}\text { Debt } \\
\text { Ratio }\end{array}$ & $\begin{array}{c}\text { Equal variances } \\
\text { assumed }\end{array}$ & -.582 & 61 & .563 & -.0475354161989 & .0816392305610 \\
\hline EPS & $\begin{array}{c}\text { Equal variances } \\
\text { assumed }\end{array}$ & .038 & 59 & .970 & 23.7418300653596 & 622.5918250103003 \\
\hline DPS & $\begin{array}{c}\text { Equal variances } \\
\text { assumed }\end{array}$ & -.297 & 59 & .767 & -160.2734204793030 & 539.3149851560811 \\
\hline
\end{tabular}

Results shows that except for ROA, for other variables, significant level is larger than 0.05 (error level). So, $\mathrm{H} 0$ is confirmed and $\mathrm{H} 1$ is rejected. So, means of these two unrelated groups 
are equal for ROE, Debt Ratio, EPS and DPS. For ROA significant level is lower than 0.05 (error level). So, $\mathrm{H} 1$ is confirmed and $\mathrm{H} 0$ is rejected. To see ROA in which group is higher, means in these two groups are compared (table $5)$.

Table 5: Mean of ROA in companies financed through shares and debt

\begin{tabular}{|l|c|r|}
\hline \multicolumn{1}{|c|}{ Variable } & Mean & Standard deviation \\
\hline ROA through Debt & 14.691698790735394 & 18.601518861111742 \\
\hline ROA through shares & 15.638771666689756 & 22.673485875488860 \\
\hline
\end{tabular}

As we can see, mean in companies financed through shares is higher than companies financed through debt. These results are confirmed by previous results. Cole (2008) concluded there is a negative relationship between financial leverage ratio and capital structure. Cole (2008) and Li et al., (2009) have studied ROA and ROS as standard of performance and concluded there is a negative relationship between Financial leverage and the ratio of short-term debt. So, Chinese's companies use less short-time debts. Some researcher suggest that managers should work on improvement of management than Liquidity development. Investors should insist on capital structure strongly, because capital structure impacts on general performance of companies. Nawaz et al (2011) examine the relationship between capital structure and corporate performance in the textile sector in Pakistan. They concluded there is a significant and positive relationship between capital structure and firm performance.

\section{Conclusion \& Discussion}

Descriptive results showed that averages of Variables of ROE, ROA, Debt Ratio, EPS and DPS have mostly normal and minor distribution. Hypothesis shown that for most variables, there is no relationship between financing through shares or debt with profitability ratios. This study show that there is not a significant statistical difference between providing financial resources through the debt method or the investment method in the four variables of ROE, DPS, EPS, and Debt Ratio. However, in the variable of ROA, there is a significant difference between the two methods: $p=0.015$. That is to say, the profitability ratio is higher in the companies that provide their financial resources through shares compared to the companies that provide their financial resources through debt. Capital structure refers to the firm's financial framework which consists of the debt and equity used to finance the firm. Capital structure is one of the popular topics among the scholars in finance field. The ability of companies to carry out their stakeholders' needs is tightly related to capital structure. Therefore, this derivation is an important fact that we cannot omit. Capital structure in financial term means the way a firm finances their assets through the combination of equity, debt, or hybrid securities. In short, capital structure is a mixture of a company's debts (longterm and short-term), common equity and preferred equity. Capital structure is essential on how a firm finances its overall operations and growth by using different sources of funds. Modigliani-Miller (MM) theorem is the broadly accepted capital structure theory because is it the origin theory of capital structure theory which had been used by many researchers. According to MM Theorem, these capital structure theories operate under perfect market. Various assumptions of perfect market such as no taxes, rational investors, perfect competition, absence of bankruptcy costs and efficient market. MM Theorem states that capital structure or finances of a firm is not related to its value in perfect market.

\section{Resources}

Agarwal, P. 2007. Institutional Ownership and Stock Liquidity.Working Paper, Cornell University.

Almeida, Heitor. and Murillo. Campello andMichael Weisbach 2004.The Cash Flow Sensitivity of Cash.Journal of Finance.59 (4), 1777-1804.

Amihud, Y. andH. Mendelsonand J. Uno 1999. Number of Shareholders and Stock Prices: Evidence from Japan. Journal of Finance.54 (3), 1169-1184.

Atanasov, V. andB. Black and C.S.CiccotelloandS.B. Gyoshev 2010. How Does Law Affect Finance? An Examination of Equity Tunneling in Bulgaria.Journal of Financial Economics.96, 155173.

Baker, Malcolm.andJeffrey. Wurgler 2002.Market Timing and Capital Structure.Journal of Finance.57, 1-32. 
Bekaert, G. andC.R. Harvey and C.Lundblad 2007. Liquidity and Expected Returns: Lesions from Emerging Markets. Review of Financial Studies.20, 1783-1831.

Berger, A.N. andE. Bonaccorsi di Patti 2006. Capital Structure and Firm Performance: ANew Approach to Testing Agency Theory and an Application to the Banking Industry. Journal of Banking and Finance.30, 1065-1102.

Bharath, S.T. and P. Pasquarielloand G. Wu 2008. Does Asymmetric Information Drive Capital Structure Decisions?.Review of Financial Studies, forthcoming.

Boyle, G.W. andP. Guthrie 2003.Investment, Uncertainty and Liquidity.Journal of Finance.58 (5), 2143-2166.

Brounen, D. and A.de Jong andK. Koedijk (2006. Capital Structure Policies in Europe: Survey Evidence. Journal of Banking and Finance.30, 1409-1442.

Chen, Y. R. 2008. Corporate Governance and Cash Holdings: Listed New Economy versusOld Economy Firms. Corporate Governance: An International Review.16, 430-442.

Chiang, R. andP.C. Venkatesh 1988. Insider Holdings and Perceptions of Information Asymmetry: a note. Journal of Finance.43 (4), 1041-1048.

Chordia, T. andR. Roll andA. Subrahmanyam 2008.Liquidity and Market Efficiency.Journal of Financial Economics.87, 249-268.

Dennis, P.J.and J. Weston 2001. Who's informed? An Analysis of Stock Ownership and Informed Trading.Working paper.Rice University.

Dittmar, A. and J. Mahrt-Smith 2007.Corporate Governance and the Value of Cash Holdings.Journal of Financial Economics.83, 599634.

Driffield, N.andV. Mahambare and S. Pal 2007.How Does Ownership Structure Affect Capital Structure and Firm Value? Recent Evidence from East Asia.Economics of Transition.15(3), 535573.

Fama, E. andK. French 2002. Testing Trade-Off and Pecking Order Predictions about Dividends and Debt. The Review of Financial Studies.15, 1-33.

Graham, J. andC. Harvey 2001. The Theory and Practice of Corporate Finance: Evidence from the
Field. Journal of Financial Economics.60, 187243.

Harford, J. 1999. Corporate Cash Reserves and Acquisitions.Journal of Finance.54, 1967-1997.

Harford, J. andS. Klasa andN. Walcott (2009). Do Firms Have Leverage Targets? Evidence from Acquisitions.Journal of Financial Economics.93, $1-14$.

Harford, Jarrad. andSattar.Mansi, and William.Maxwell 2008, Corporate Governance and a Firm's Cash Holdings.Journal of Financial Economics.87, 535-555.

Heflin, F. and K.W. Shaw 2000 .Block holderOwnership and Market Liquidity. Journal of Financial and Quantitative Analysis.35 (4), 621633.

Hovakimian, A. 2006. Are Observed Capital Structures Determined by Equity Market Timing? Journal of Financial Quantitative Analysis.41, 221-2443.

Huang, Samuel G. H. andFrank M. Song 2006. The Determinants of Capital Structure: Evidence from China. China Economic Review.17, 14-35.

Isshaq, Z. and A.Godfredand J. Bokpin and M. Onumah 2009.Corporate Governance, Ownership Structure, Cash Holdings, and Firm Value on the Ghana Stock Exchange.The Journal of Risk Finance.10(5), 488-499.

Kalcheva, Ivalina.and Karl V. Lins 2007..International Evidence on Cash Holdings and Expected Managerial Agency Problems.Review of Financial Studies.20, 10881112.

Kim, Chang-Soo.andDavid C. MauerandAnn. E. Sherman 1998. The Determinants of Corporate Liquidity: Theory and Evidence. Journal of Financial and Quantitative Analysis.33, 335-359.

Kothare, M. 1997. The Effects of Equity Issues on Ownership Structure and Stock Liquidity: AComparison of Rights and Public Offerings. Journal of Financial Economics.43 (1), 131-148.

Laeven, L. andR. Levine 2008.Complex Ownership Structures and Corporate Valuations.Review of Financial Studies.21, 579-604.

Lang, M.H. and K.V.LinsandD.P. Miller 2004. Concentrated Control, Analyst Following, and Valuation: Do Analysts Matter Most When Investors Are Protected Least?.Journal of Accounting Research.42, 589-623. 
Lefort, F. andF. Urzua 2008. Board Independence, Firm Performance and Ownership Concentration: Evidence from Chile. J Bus Res.61, 615-22.

Leland, H.E. 1994. Corporate Debt Value, Bond Covenants and Optimal Capital Structure.Journal of Finance.49, 1213-1252.

Leland, H.E. 1998. Agency Costs, RiskManagement and Capital Structure. Journal of Finance.53, 1213-1243.

Leland, H.E. and K.B. Toft 1996.Optimal Capital Structure, Endogenous Bankruptcy and the Term Structure of Yield Spreads.Journal of Finance.51, 987-1019.

Liu, L.X.L 2005. Do Firms Have Target Leverage Ratios? Evidence from Historical Market-to-Book and Past Return.WFA meetings, Portland, OR.

Loughran, T. andP. Schultz 2005. Liquidity: Urban Versus Rural Firms. Journal of Financial Economics.78, 341-374.

Loughran, T. andP. Schultz 2008.The Impact of Location on Equity Issuance.Financial Management.37, 1-21.

Lucas, Deborah J. and Robert L. McDonald 1990.Equity Issue and Stock Price Dynamics.Journal of Finance.45, 1019-1043.

Lyandres, E. 2006. Capital Structure and Interaction amongFirms in Output Markets: Theory and Evidence. Journal of Business.79, 2381-2421.

Mauer, D.C. andA.J. Triantis 1994. Interactions of Corporate Financing and Investment Decisions: A Dynamic Framework. Journal of Finance.49, 1253-1277.

Menendez-Alonso, E. J. 2003. Does Diversification Strategy Matter in Explaining Capital Structure?
Some Evidence from Spain.Applied Financial Economics.13, 427.

Modigliani, F. and M. H.Miller 1963. Corporate Income Taxes and the Cost of Capital: A Correction. American Economic Review.53, 433443.

Modigliani, F. andM.H. Miller 1958.The Cost of Capital, Corporation Finance and the Theory of Investment.American Economic Review.48, 261297.

Myers, Stewart C. andMajluf, S. Nicholas 1984. Corporate Financing and Investment Decisions When Firms Have Information thatInvestors Do Not Have. Journal of Financial Economics.13, 187-221.

Opler, T. andS. Titman 1994. Financial Distress and Corporate Performance. In: The Journal of Finance.49(3), 1015-1040.

Rajan, R. andL. Zingales 1995. What Do We Know About Capital Structure? Some Evidence from International Data.Journal of Finance.50, 14211460 .

Riddick, L.A. and T.M. Whited 2009. The Corporate Propensity to Save.Journal of Finance.64, 17291766.

Rubin, A. 2007. Ownership Level, Ownership Concentration and Liquidity.Journal of Financial Markets.10 (3), 219-248.

Sarin, A. andK.A. Shastri andK. Shastri 2000.Ownership Structure and Stock Market Liquidity.Working paper.University of Pittsburgh.

Welch, Ivo. 2004. Capital Structure and Stock Returns. Journal of Political Economy.112, 106131 